\title{
TIMING OF THE THREE MILE
UNIT 2 CORE DEGRADATION AS DETERMINED BY FORENSIC ENGINEERING
}

JAMES O. HENRIE Hydrogen Control, Inc PO Box 516, Pangutch, Utah 84759

Received October 5, 1988

Accepted for Publication March 28, 1989
NUCLEAR SAFETY

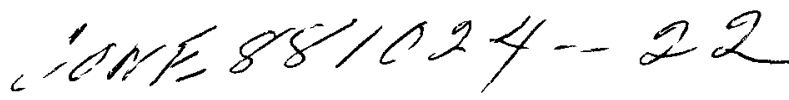

\section{DE90 007045}

generated until zurconium temperatures exceed $650^{\circ} \mathrm{C}$ $\left(1200^{\circ} \mathrm{F}\right)$

There are many difficulties and uncertannties asso-

Unlike computer simulation of an event, forensic engineering is the evaluation of recorded data and damaged as well as surviving components after an event to determine progressive causes of the event. Such an evaluation of the 1979 Three Mile Island Unit 2 accldent indicates that gas began accumulating in steam generator $A$ at 6.10 , or $130 \mathrm{~min}$ into the accident and, therefore, fuel cladding ruptures and/or zirconiumwater reactions began at that time. Zirconium oxidatıon/hydrogen generatıon rates were highest $1 \sim 70 \mathrm{~kg}$ of hydrogen per minute) during the core quench and collapse at $175 \mathrm{~min}$. By $180 \mathrm{~min}$, over $85 \%$ of the hydrogen generated by the zirconium-water reaction had been produced, and $\sim 400 \mathrm{~kg}$ of hydrogen had accumulated in the reactor coolant system. At that time, hydrogen concentrations at the steam/water interfaces in both steam generators approached 90\%. By $203 \mathrm{~min}$, the damaged reactor core had been reflooded and has not been uncovered since that time. Therefore, the core was completely under water at $225 \mathrm{~min}$, when molten core material flowed into the lower head of the reactor vessel.

\section{EMPIRICAL METHODS FOR DETERMINING HYDROGEN GENERATION}

Hydrogen $\left(\mathrm{H}_{2}\right)$ is generated in a degrading watercooled nuclear reactor by radiolysis and metal-water reactions. In the Three Mile Island Unit 2 (TMI-2) lossof-coolant accident (LOCA), $\mathrm{H}_{2}$ generated by radiolysis was probably insignificant compared with that produced by the reaction of zirconium with water. Baker ${ }^{1}$ provides data (used in Fig. 1) from a number of researchers ${ }^{1-3}$ showing that zurconium-water reaction rates are temperature dependent. The data sources are in reasonably good agreement, and very little $\mathrm{H}_{2}$ is crated with the calculation of $\mathrm{H}_{2}$ generation rates and quantities that occurred during the TMII-2 event. If the calculations rely on the use of the empirical metalwater reaction rate versus temperature data, some of the uncertainties include, or are a result of,

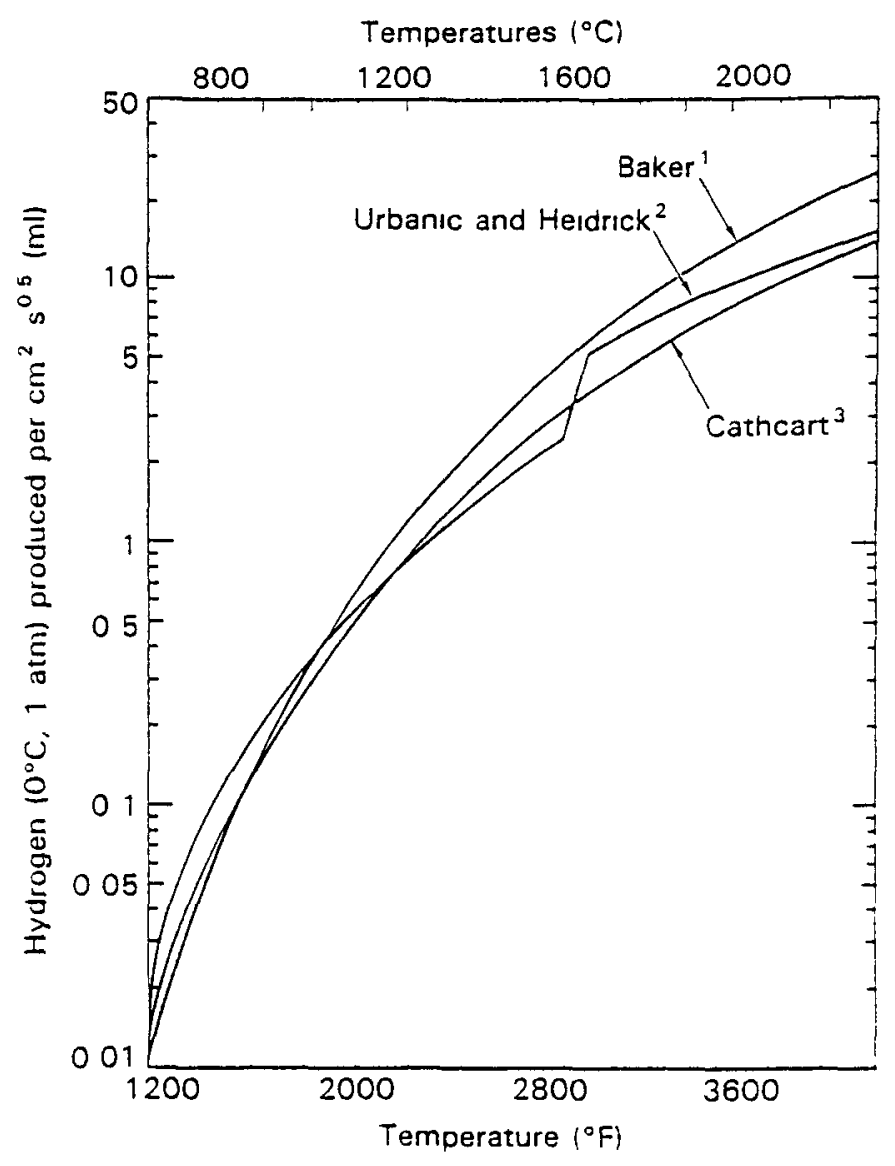

Fig 1 Comparison of zirconium-water reaction correlations. 


\section{DISCLAIMER}

This report was prepared as an account of work sponsored by an agency of the United States Government. Neither the United States Government nor any agency Thereof, nor any of their employees, makes any warranty, express or implied, or assumes any legal liability or responsibility for the accuracy, completeness, or usefulness of any information, apparatus, product, or process disclosed, or represents that its use would not infringe privately owned rights. Reference herein to any specific commercial product, process, or service by trade name, trademark, manufacturer, or otherwise does not necessarily constitute or imply its endorsement, recommendation, or favoring by the United States Government or any agency thereof. The views and opinions of authors expressed herein do not necessarily state or reflect those of the United States Government or any agency thereof. 


\section{DISCLAIMER}

Portions of this document may be illegible in electronic image products. Images are produced from the best available original document. 
1. time the core began to uncover

2. coolant makeup flow rates and boildown rates

3. changing heat movement means, paths (horizontal and vertical components) and rates with changing water levels, steam generation rates, $\mathrm{H}_{2}$ generation rates, and physical changes such as cladding ballooning from overheating and cladding swelling from oxidation

4. changing surface areas as cracking and flaking of oxide layers expose more unoxidized metal

5. Zircaloy melting and relocation to generally colder regions and resulting reduced exposed surface areas

6. timing and effects of core shifts, quenching, collapse, reheating, etc.

Another approach to approximating TMI-2 $\mathrm{H}_{2}$ generation rates versus time is to evaluate available thermal-hydraulic data.

\section{SEQUENCE OF EVENTS CAUSING HYDROGEN GENERATION}

\section{Initial Core Heatup}

In the TMI-2 LOCA, steam from the reactor core moved to the pressurizer, out through the pressurizer relief valve (PRV) to the coolant drain tank, and to the containment building. The water level in the reactor core dropped below the top of the active fuel, and the upper region of the core started to overheat as early as $5: 50$, or 110 min after initiation of the accident; this time is shown as the Modular Accident Analysis Program (MAAP) best estimate by Kenton et al. ${ }^{4}$ The MAAP best estimate is that by $130 \mathrm{~min}(6: 10)$ the water level in the core was below $7 \mathrm{ft}$ (up from the bottom of the 12-ft-high active core section). As the zirconium cladding was uncovered and its temperature approached $650^{\circ} \mathrm{C}\left(1200^{\circ} \mathrm{F}\right), \mathrm{H}_{2}$ generation started. Since the zirconium-water reaction is highly exothermic, temperatures rose at increasing rates.

\section{Steam Generator Conditions}

Early in the LOCA, the secondary side of the oncethrough steam generators (OTSGs) $A$ and $B$ boiled dry and were, therefore, thermally isolated from the primary system. However, by $120 \mathrm{~min}$ (6:00), the water level in the secondary side of OTSG-A rose to the $50 \%$ operating range level. Refluxing (steam condensing on the primary side of the OTSG) occurred as evidenced by decreasing primary system pressures. The cold water addition to the secondary side of OTSG-A reduced its steam pressure initially, but its pressure leveled off as temperatures stabilized. At $132 \mathrm{~min}$ (6:12), the OTSG-A steam pressure started decreasing again at the same rate it had been when the secondary side was dry. Also at $132 \mathrm{~min}$, the primary system pressure reversed its downward trend and started to increase. A probable explanation for this behavior is the accumulation of $\mathrm{H}_{2}$ in the primary system, causing its pressure to rise and the steam sweeping of $\mathrm{H}_{2}$ to OTSG-A, thereby blocking it and preventing refluxing operation. ${ }^{a}$ According to Kenton et al., the amount of $\mathrm{H}_{2}$ required to effectively block steam flow to OTSG-A is very small, possibly $<1 \mathrm{~kg}$, when the secondary water level is near (apparently not more than a few feet higher) that of the primary side. ${ }^{+}$

\section{Core Damage and Hydrogen Generation Timing}

After $-132 \mathrm{~min}, \mathrm{H}_{2}$ was generated at increasing rates as water levels in the core continued to drop and zirconium cladding temperatures continued to rise. At 174 min $(6: 54)$, reactor coolant pump $2 B$ was started and pumped water from OTSG-A to the reactor core for a number of seconds, effectively flooding and quenching the core, causing it to collapse. There is much undisputed evidence of the core collapse at that time, including the sudden drop in the power range monitor output, as shown in Fig. 2. This drop could not have been due to water shielding since it had only partially recovered by $200 \mathrm{~min}(7: 20)$, when the water level in the core was again low, and no similar drop occurred when the core had been reflooded by $203 \mathrm{~min}$. After the core quench, water levels again decreased to -30 in. above the bottom of the active core, as indicated by an analysis of self-powered neutron detector data. The partially destroyed core reheated; at $230.5 \mathrm{~min}$ (7:20:30) (see Fig. 3), makeup pump (MUP) $1 \mathrm{C}$ was started and left on until the core was completely reflooded and the pressurizer refilled. The cooling effect decreased the system pressure and caused the pressurizer to start to drain, thereby assisting in the rapid flooding of the core. The system pressure leveled off, and flow from the pressurizer stopped and reversed slightly for $-30 \mathrm{~s}$ as the reheated core again quenched. Since that transient was so small compared to the one at $174 \mathrm{~min}(6: 54)$ or the one at $225 \mathrm{~min}(7: 45)$, it is certain that the upper half of the core, in its collapsed condition, had not overheated to the extent that it produced large quantities of $\mathrm{H}_{2}$ for a second time. Water from the MUP and pressurizer continued to enter the reactor vessel. By $208 \mathrm{~min}(7: 28)$, the water level was above the vessel nozzles, and the pressure was high enough to reverse the flow of water back into the pressurizer. No evidence has been found indicating that the water level in the reactor vessel has ever been below the level of the nozzles since that time. Therefore, the upper

\footnotetext{
Also, gas leaking from ruptured fuel pins has not been thoroughly evaluated, but it may have had a significant initial effect on system pressure rise and steam generator blocking.
} 


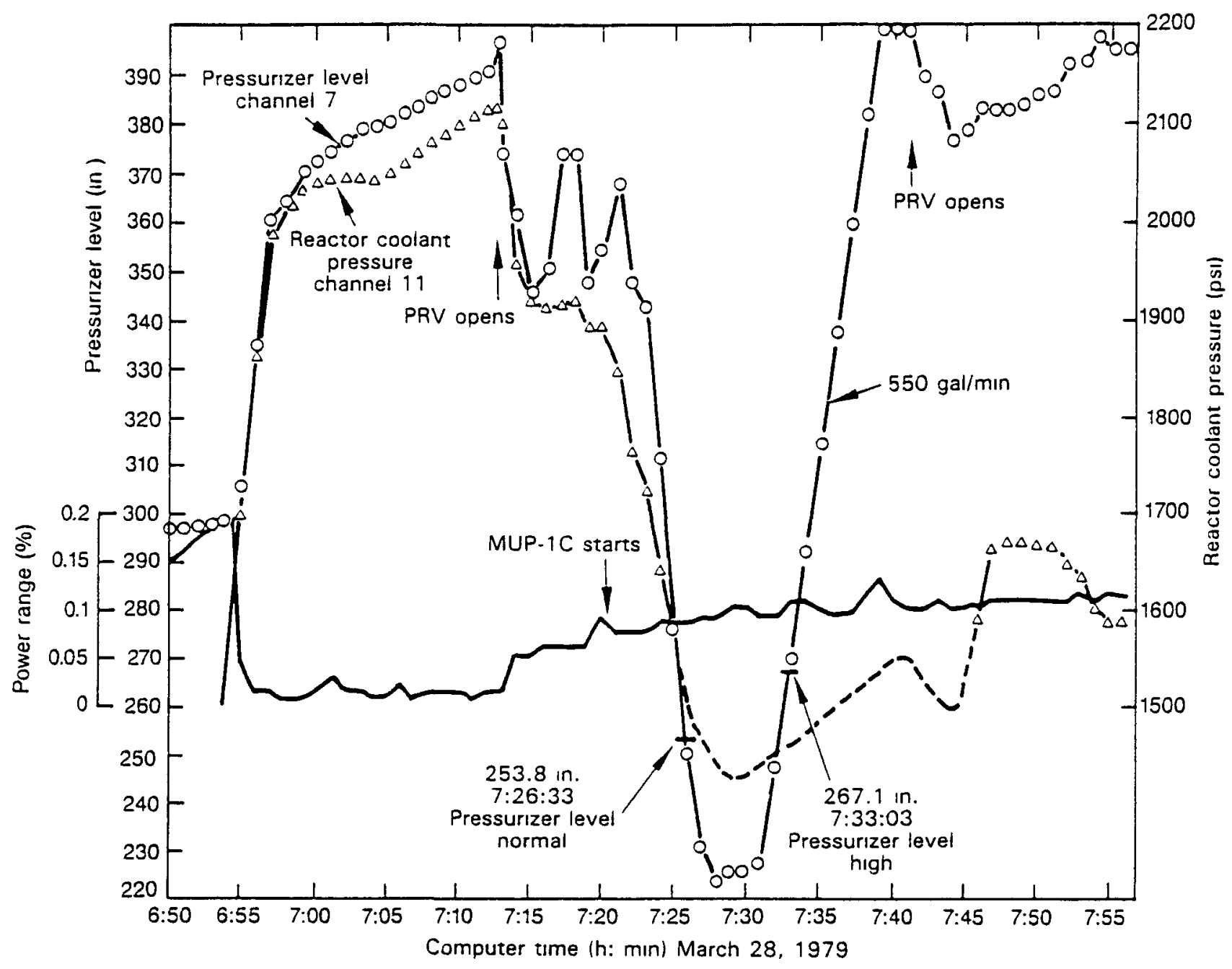

Fig. 2. Selected responses to the $6: 54,7: 21$, and 7:45 transients.

half of the core has not been reheated, and it can be concluded that essentially all of the damage to the upper half of the core occurred before $180 \mathrm{~min}(7: 00)$, when the core had been quenched, and certainly before 203 min (7:23), when the collapsed, readily coolable upper half of the core was flooded for the last time.

\section{Hydrogen Generation}

An evaluation of the extensive damage to the upper half of the core indicates that $-80 \%$, or $-9400 \mathrm{~kg}$ (not fully substantiated at this time) of the zirconium in the upper half of the core was oxidized in that region. The reaction of that amount of zurconium with water would produce $>400 \mathrm{~kg}$ of $\mathrm{H}_{2}$, or $-90 \%$ of the total $460 \mathrm{~kg}$ of $\mathrm{H}_{2}$ accounted for by Henrie and Postma. ${ }^{5}$

Even though the damaged core was under water, coolant flow through the core was blocked near its mid-elevation by core debris that might still have been partially molten. That poorly cooled mass reheated from fission product decay heat, and the mass of molten material continued to grow. That condition had been terminated by $228 \min (7: 48)$, when $-20 \mathrm{t}$ (Ref. 6) of molten core material had moved laterally and down around the lower core support structure into the lower head region of the reactor vessel, where it solidified and fragmented. The amount of $\mathrm{H}_{2}$ produced in the totally submerged core during this period (203 to $228 \mathrm{~min}$, or $7: 23$ to $7: 48$ ) was probably only a small fraction of $\mathrm{H}_{2}$ generated earlier, because

1. while the molten mass was reforming, the area of very hot zirconium exposed to steam was probably relatively small

2. the fuel in the core below the once-molten mass was undamaged and, therefore, was well cooled

3. zirconium, when exposed to very hot uranium dioxide, takes oxygen from the uranium dioxide, and no $\mathrm{H}_{2}$ is produced

4. when the molten material was quenched, it already contained significant quantities of oxygen and therefore, would not react rapidly with steam. 


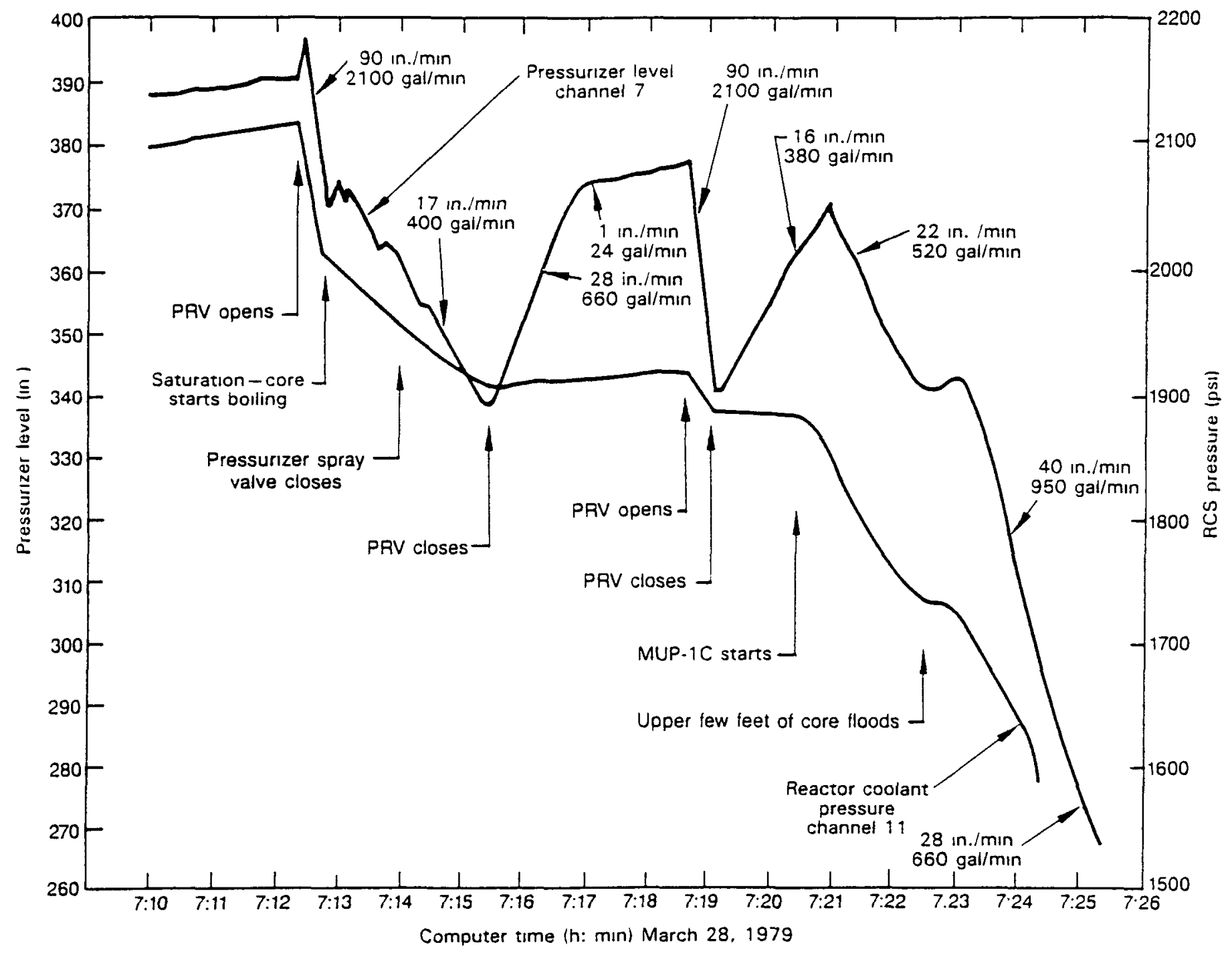

Fig. 3. Pressurizer level and system pressure during venting and core flooding.

The quantity of $\mathrm{H}_{2}$ produced during this period appears to have been $\sim 60 \mathrm{~kg}$ ( $460 \mathrm{~kg}$ total minus $400 \mathrm{~kg}$ produced earlier). After $228 \mathrm{~min}$, there appear to have been no high-temperature metal conditions that would have resulted in significant $\mathrm{H}_{2}$ production from metalwater reactions.

\section{HYDROGEN CONCENTRATIONS AND QUANTITIES IN THE REACTOR COOLANT SYSTEM}

\section{Hydrogen Concentrations}

The large regions of the reactor cooling system (RCS) that stored $\mathrm{H}_{2}$ during the accident are the reactor vessel, pressurizer, hot legs, and the upper sections of the stearn generators. Hydrogen concentrations and the quantities of $\mathrm{H}_{2}$ stored in the hot legs and hydrogen-blocked steam generators can be approximated from available system pressure and steam pressure data. When the water levels on the primary and sec- ondary sides of the near-idle steam generators are approximately equal, temperatures and steam pressures on both sides would be approximately equal. Therefore, the difference between the system total pressure and the steam pressure can be attributed to the presence of a noncondensable gas, or $\mathrm{H}_{2}$ in this case.

Pressure data from the reactimeter, computer utility printer, and the RC-3A-PT3 stripchart were obtained and correlated. Dynamic conditions and differences in elevation were accounted for in preparing the basis for correcting (calibrating) the stripchart record. A corrected stripchart pressure history for the period between 130 and $175 \mathrm{~min}$ (6:10 and 6:55) was prepared ${ }^{7}$ and compared with the composite pressure history prepared by the Nuclear Safety Analysis Center ${ }^{3}$ (NSAC). Steam pressures and system pressures $>11000 \mathrm{kPa}$ (1600 psi) are available from the reactimeter. From the data shown in Table I, the $\mathrm{H}_{2}$ concentration at the interface with water in the steam generators can be calculated (total pressure minus steam pressure, divided 


\section{TABLE I}

Total Pressure in the RCS and Steam Pressure in the OTSGs A and B. Durnng the Principal Hydrogen Generation Period

\begin{tabular}{|l|c|c|c|c|}
\hline \multirow{2}{*}{ Time } & \multicolumn{2}{|c|}{$\begin{array}{c}\text { Total Pressure } \\
\text { (lb/in. }\end{array}$} & \multicolumn{2}{c|}{$\begin{array}{c}\text { Steam Pressure } \\
\text { (lb/in. }\end{array}$} \\
\cline { 2 - 5 } & $\begin{array}{c}\text { NSAC } \\
\text { Composite }\end{array}$ & $\begin{array}{c}\text { Current } \\
\text { Composite }\end{array}$ & OTSG-A & OTSG-B \\
\hline $6: 10$ & 610 & 631 & 600 & $a$ \\
$6: 12$ & 603 & 621 & 591 & $a$ \\
$6: 14.5^{5}$ & 615 & 636 & 579 & $a$ \\
$6: 27$ & 680 & 685 & 518 & $a$ \\
$6: 37$ & 805 & 831 & 457 & $a$ \\
$6: 54.5$ & 1200 & 1244 & 358 & 140 \\
$6: 55.5^{\text {b }}$ & 1674 & 1674 & 361 & 718 \\
$6: 57$ & 1990 & 1990 & 354 & 577 \\
$6: 58$ & 2026 & 2026 & 348 & 545 \\
$7: 00$ & 2043 & 2043 & 327 & 458 \\
$7: 05$ & 2051 & 2051 & 281 & 359 \\
$7: 10$ & 2100 & 2100 & 241 & 363 \\
$7: 12.3^{\mathrm{c}}$ & 2119 & 2119 & 224 & 370 \\
$7: 15.5^{\mathrm{d}}$ & 1907 & 1907 & 206 & 375 \\
$7: 18.6^{\mathrm{c}}$ & 1920 & 1920 & 189 & 377 \\
$7: 19^{\mathrm{d}}$ & 1887 & 1887 & 185 & 376 \\
$7: 20.5^{\mathrm{e}}$ & 1883 & 1883 & 181 & 376 \\
$7: 23$ & 1721 & 1721 & 163 & 372 \\
$7: 24$ & 1637 & 1637 & 157 & 370 \\
\hline
\end{tabular}

${ }^{2}$ The secondary side of OTSG-B had boiled dry; therefore, the steam pressure on the primary side is unknown.

${ }^{b}$ After $6: 55.5$, all data are from the reactimeter.

cPRV opened.

dPRV closed.

${ }^{\mathrm{e}} \mathrm{MUP}-1 \mathrm{C}$ came on.

by total absolute pressure) to an accuracy within a few percent. These $\mathrm{H}_{2}$ concentration results are presented in Fig. 4, which indicates that $\mathrm{H}_{2}$ began to accumulate in OTSG-A as early as $130 \mathrm{~min}(6: 10)$. By $190 \mathrm{~min}$ (7:10), $\mathrm{H}_{2}$ concentrations at the water/gas vapor interface in both steam generators was $>80 \%$ by volume.

\section{Hydrogen Quantities}

Based on the conservatively low assumption that $\mathrm{H}_{2}$ concentration decreases linearly from its maximum at the water interface in the steam generators to zero, where the hot leg attaches to the reactor vessel, and making appropriate temperature corrections, total quantities of $\mathrm{H}_{2}$ in the known volumes of the hot legs and steam generators were calculated. The results are plotted in Fig. 5, which indicates that after $180 \mathrm{~min}$ $(7: 00),>300 \mathrm{~kg}$ of $\mathrm{H}_{2}$ was stored in the steam generators and hot legs until it was removed by venting (starting at $192 \mathrm{~min}$ ) and cooling the core (starting at

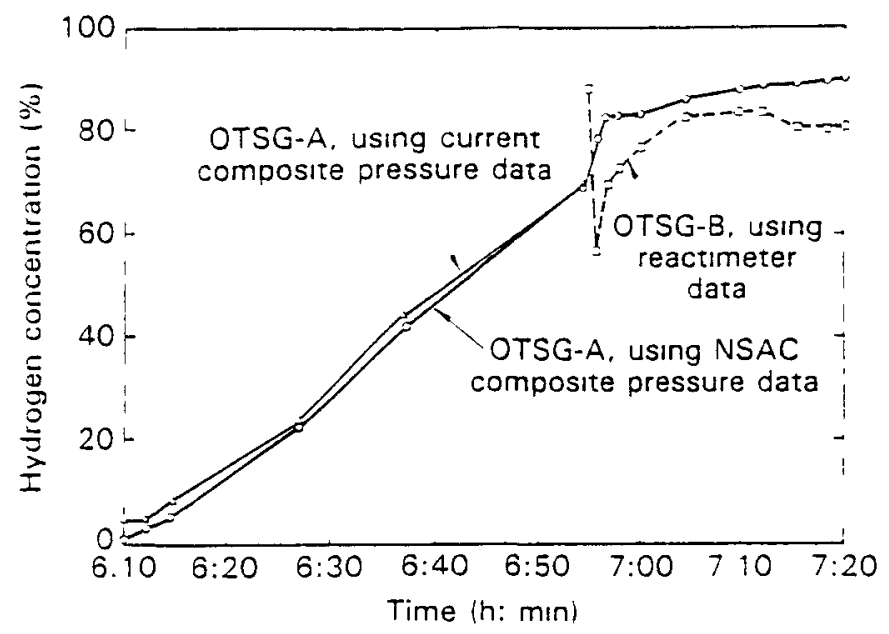

Fig. 4. Calculated hydrogen concentration versus time near the water interface in OTSGs $\mathrm{A}$ and $\mathrm{B}$.

200 min). During that period, the total RCS void (vapor/gas) volume was $-170 \mathrm{~m}^{3}\left(-6000 \mathrm{ft}^{3}\right)$, of which $63 \%$ was in the hot legs and steam generators, $33 \%_{0}$ in the reactor vessel, and $4 \%_{0}$ in the pressurizer. Since the steam source was in the reactor vessel, the vapor content there was higher than in the hot legs and steam generators. Consequently, the mass of $\mathrm{H}_{2}$ in the hot legs and steam generators would have been higher than $63 \%$ of the total, implying that a total of $\sim 400 \mathrm{~kg}$ $(>300 />0.63 \approx 400)$ of $\mathrm{H}_{2}$ may have been stored in the RCS at that time. A more recent calculation - assuming a linear distribution of $\mathrm{H}_{2}$ from $80 \%$ at the water surface in the steam generators to zero at the water surface in the core, and making appropriate temperature corrections - indicated a total of $430 \mathrm{~kg}$ of $\mathrm{H}_{2}$ in the RCS at $192 \min (7: 12)$.

\section{HYDROGEN PRODUCTION RATES}

To approximate $\mathrm{H}_{2}$ production as a function of time, an analysis of the RCS pressure history was made, and two bounding sets of assumptions (cases 1 and 2) were established to relate $\mathrm{H}_{2}$ produced to system pressure. The results are shown in Fig. 6. The case 1 analysis is based on the production of $400 \mathrm{~kg}$ of $\mathrm{H}_{2}$ by $178 \mathrm{~min}(6: 58)$ and an arbitrary assumption that the $\mathrm{H}_{2}$ generation rate remained constant through the core quench. Case 1 is intended as the bounding case for earliest $\mathrm{H}_{2}$ generation. Case 2 is based on the production of $400 \mathrm{~kg}$ of $\mathrm{H}_{2}$ by $200 \mathrm{~min}(7: 20)$ and that $\mathrm{H}_{2}$ generation was proportional to system pressure, even through the quench transient. Case 2 is intended as the bounding case for latest $\mathrm{H}_{2}$ generation.

To determine whether the metal-water reaction was steam starved (reaction rates limited by steam generation rates), an analysis of steam generation rate versus water level in the reactor core was made and compared 


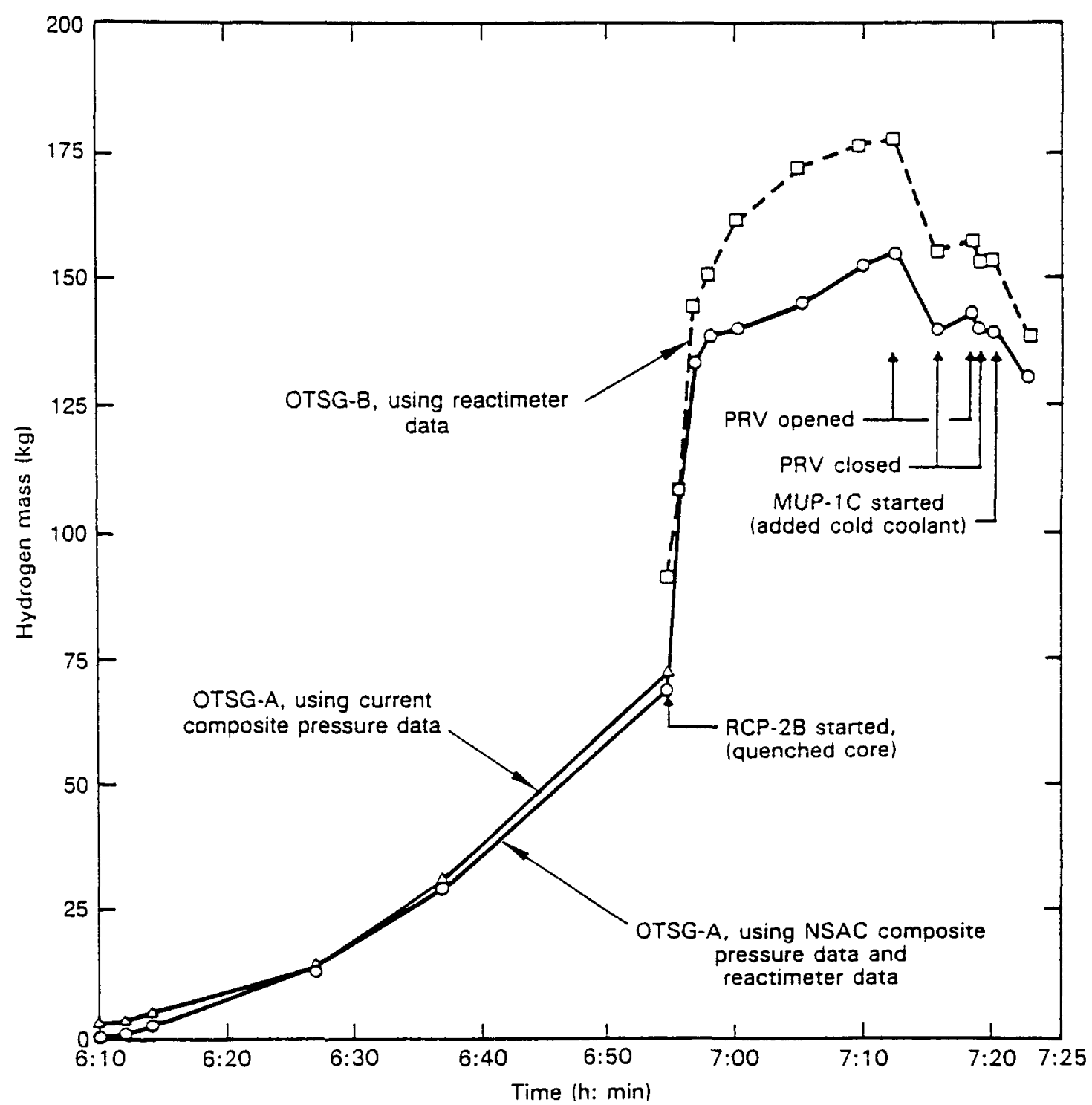

Fig. 5. Caiculated mass of hydrogen versus time in hot legs and OTSGs A and B.

with the $\mathrm{H}_{2}$ generation rates. It appears that for the few minutes preceding the quench, the steam generation rate was low enough to have limited $\mathrm{H}_{2}$ production to $-20 \mathrm{~kg} / \mathrm{min}$. Therefore, for case 1 conditions, the reaction may have been steam limited $(\sim 18 \mathrm{~kg} / \mathrm{min})$ during that period. However, the reaction would not have been generally steam limited during that period for the case $2(\sim 8 \mathrm{~kg} / \mathrm{min})$ conditions. Therefore, the increased $\mathrm{H}_{2}$ generation rate $(\sim 70 \mathrm{~kg} / \mathrm{min})$ during the case 2 quench conditions would not have been caused simply by the increased availability of water vapor during the quench. The sudden increase is likely to have resulted from geometry changes that occurred when the upper half of the core collapsed at the beginning of the core quench. The core collapse resulted in the fragmentation of cladding, which greatly increased the exposure of unoxidized and partially oxidized zirconium to the steam. The resulting increases in reaction rates (highly exothermic) rapidly increased temperatures (each progressively increasing the other), and with increased generation rates, autocatalytic (runaway) conditions occurred until zirconium surfaces were well oxidized and temperatures were lowered by steam cooling. It is likely that the peak core temperatures $(>3100 \mathrm{~K}$ or $5100^{\circ} \mathrm{F}$ - the melting point of uranium dioxide) occurred during this core quench period.

An apparent problem with the case 1 results is that so much energy would have been released from the exothermic metal-water reaction before the quench that it would have caused more damage to the core, core former, and plenum assembly than has been observed. In case 2, almost half of the zirconium oxidation occurred during the core quench period. Most of the reaction heat released at that time would have been used in the boiling of water, which would minimize metal overheating even though the core became very 


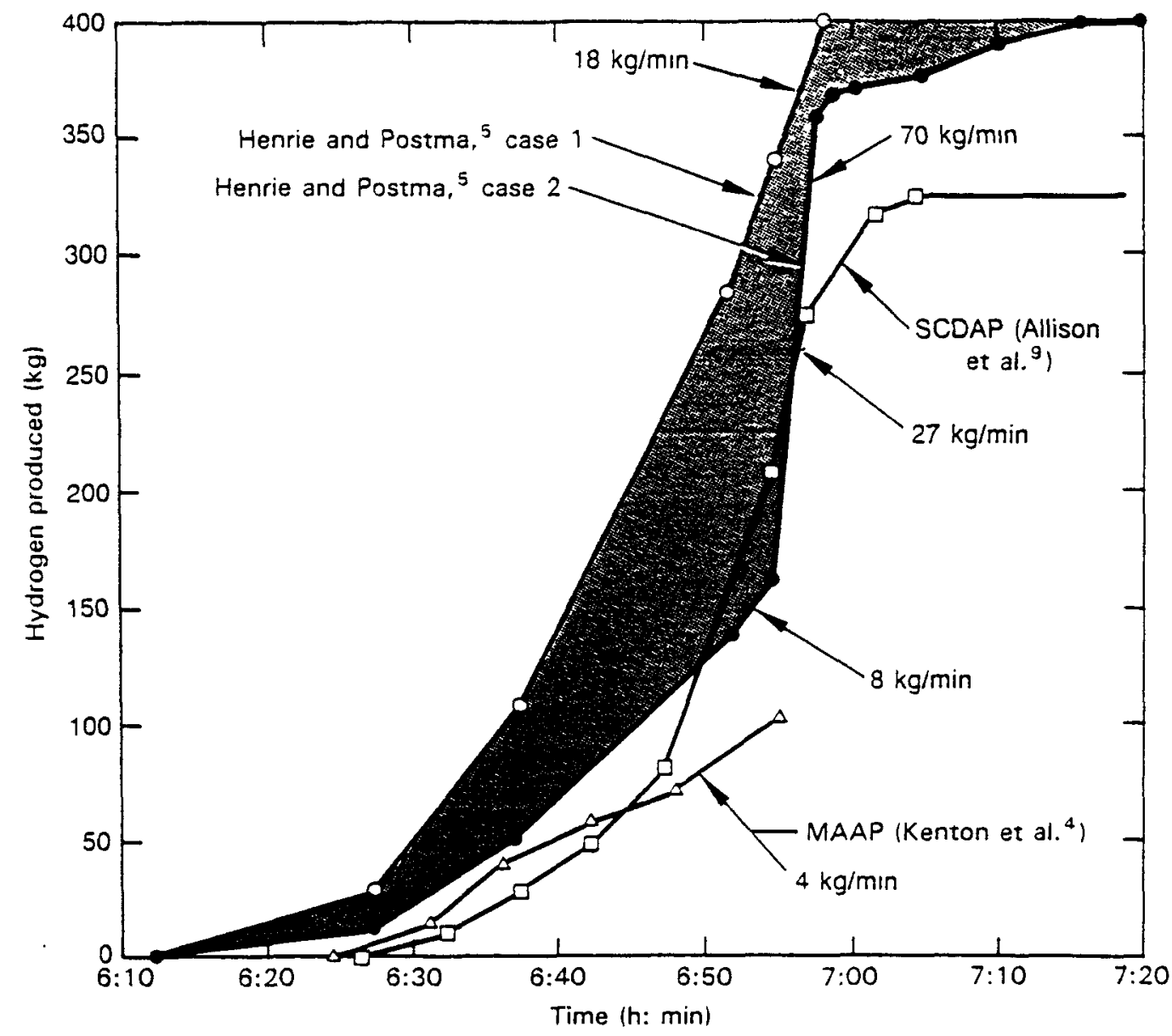

$\operatorname{Re} \div, 5,0 K:$

Ref. $9,0 x$ ?

ReF. 4 , OK?

Fig. 6. Calculated TMI-2 hydrogen production from the zirconium-water reaction.

hot. It is believed that the actual $\mathrm{H}_{2}$ production rates and timing were between the two bounding cases shown in Fig. 6, but for the reasons stated, they were apparently much closer to case 2 than to case 1 . Figure 6 shows that the result of case 2, compared to that of case 1, is much closer to the results of SCDAP (Ref. 9) and MAAP (Ref. 4).

Figure 7 shows the production timing $460 \mathrm{~kg}$ of $\mathrm{H}_{2}$ that was accounted for by Henrie and Postma. ${ }^{5}$ The figure also shows their latest estimates ${ }^{7}$ of quantities of $\mathrm{H}_{2}$ gas in the containment building (but outside of the RCS) as a function of time. Therefore, the estimated amount of $\mathrm{H}_{2}$ contained in the RCS at any time between $132 \min (6: 12$, when measureable quantities of $\mathrm{H}_{2}$ first started to accumulate) and $590 \mathrm{~min}$ (13:50, when the $\mathrm{H}_{2}$ burn in the containment building occurred) is the difference between the two curves.

\section{OTHER CORE DAMAGE OBSERVATIONS}

The forensic engineering approach has also provided a probable explanation for the overhang of partially damaged fuel bundles on the west side (at fuei grid locations $\mathrm{C7}$ and $\mathrm{C} 8$ ) near the top of the reactor core and for the fact that the stainless steel plenum above the reactor core did not melt during the intense core heating period. An examination of system components and recorded data indicates that water moved from the core, where temperatures and pressures were increasing, to the closed pressurizer, where it condensed (increasing the temperature of the water in the pressurizer) and returned water intermittently (unstable conditions) through hot leg A to directly cool that side of the core and the plenum.

Through a study of the RCS pressures, responses of in-core thermocouples and self-powered neutron detectors, and steam generator and cold-leg temperatures, it was determined that a portion of the core meited and flowed into the lower head. Many months later, the study was confirmed by remote television pictures that showed quenched, once-molten core material in the lower head. The forensic study also indicated that the material may have reached the lower head by flowing down the east side of the core near fuel grid location R7. The thermocouple at that location formed a new junction $4 \mathrm{ft}$ below the bottom of the core between $7: 45: 11$ and $7: 45: 41$. This was discussed ${ }^{10}$ at 


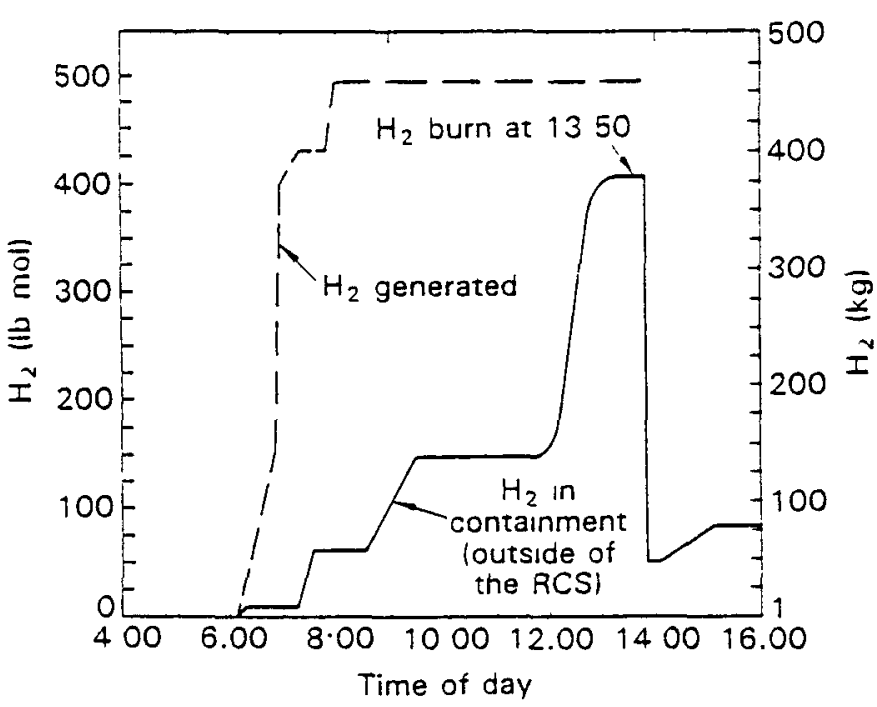

Fig. 7 TMI-2 hydrogen generation and accumulation in containment.

TMI but seemed incredible; thus, it was discounted at that time because more heat is generated along the vertical centerline of the core, and it was thought that the molten material would surely penetrate near there. Only recently, during rector defueling, was it determined that the flow had actually occurred on the east side between the core former and the core barrel. A better evaluation of the data in early 1985 would have assisted the defueling operation.

Much can be learned from the forensic enganeenng evaluation of data and damaged components following accidents such as the TMI-2 LOCA. Where destruction is more complete and little data and few components are available for evaluation, such as at Chernobyl, evaluators must resort primanly to computenzed modeling. In any event, validated computer modeling of severe accidents is necessary to allow hypothetical accident evaluations of varıous exısting and improved future designs.

\section{ACKNOWLEDGMENT}

This work was partially supported by the U.S. Department of Energy, Office of Light Water Reactor Safety and Technology.

\section{REFERENCES}

1. L. BAKER Jr., "An Assessment of Existing Data on Zirconium Oxidation Under Hypothencal Accident Condıtions in Light-Water Reactors," ANL/LWR/SAF 83-3, Argonne National Laboratory (1983).

2. V F URBANIC, T. R. HEIDRICK, "High Temperature Oxidation of Zircaloy-2 and Zircaloy-4 on Steam," $J$. Nucl. Mater., 75, 251 (1978).

3. J. V. CATHCART, "Quarterly Progress Report on the Zirconium Metal-Water Oxidation Program Sponsored by the NRC Division of Reactor Safety Research for OctoberDecember, 1976," ORNL-NUREG-87, Oak Rudge National Laboratory (1977).

4. M. A. KENTON, R. E. HENRY, A. SHARON, M. EPSTEIN, G. R. THOMAS, L. J. RUDY, M. MEERBAUM, and J. AZZARELLO, "Simulation of the TMI-2 Accident Using the MAAP Modular Accident Analysis Program, Version 2.0," EPRI-NP-4292, Electric Power Research Institute (1986).

5. J. O. HENRIE and A. K. POSTMA, "Analysis of the Three Mile Island Unit 2 Hydrogen Burn," RHO-RE-SA-8 Rev. 2, Rockwell Hanford Operations (1983); see also GEND-INF-023, Vol. IV

6. E. R. CARLSON and B. A. COOK, "Chemical Interaction Between Core and Structural Materials," Proc. ISt Int. Information Mtg. TMI-2 Accident, CONF-8510166, EG\&G Idaho, Inc. (1985).

7. J. O. HENRIE and A. K. POSTMA, "Lessons Learned from Hydrogen Generation and Burning Durnng the TMI Event," RHO-RE-EV-95, Rockwell Hanford Operations (1987); see also GEND-061.

8. "Analysis of the Three Mile Island Unit 2 Accident," EPRI-NSAC-1, Electric Power Research Institute (1979).

9. C. M. ALLISON, S. T. POLKINGHORNE, and M. S. SOHAL, "SCDAP/MOD1 Analysis of the Progression of Core Damage During the TMI-2 Accident," EGG-SAR7104, EG\&G Idaho, Inc. (1985).

10. H. M. BURTON and J. O. HENRIE, undocumented discussions concerning the possibility of moiten core material flowing down the east side of the TMI-2 core as indicated by thermocouple and self-powered neutron detector data, Three Mile Island, 8:00 A.M., March 24, 1985.

\section{DISCLAIMER}

\footnotetext{
This report was prepared as an account of work sponsored by an agency of the United States Government Neither the United States Government nor any agency thereof, nor any of their employees, makes any warranty, express or implied, or assumes any legal liability or responsibility for the accuracy, completeness, or usefulness of any information, apparatus, product, or process disclosed, or represents that its use would not infringe privately owned rights Reference herein to any specific commercial product, process, or service by trade name, trademark, manufacturer, or otherwise does not necessarily constitute or imply its endorsement, recommendation, or favoring by the United States Government or any agency thereof The views and opinions of authors expressed herein do not necessarily state or reflect those of the United States Government or any agency thereof
} 